Jurnal Pengabdian Masyarakat

vol.1 no.1 Oktober 2017

\title{
PENYULUHAN BAITUL MAL WAT TAMWIL (BMT) DI DESA KARYA INDAH KEC. TAPUNG, KAB. KAMPAR \\ Mohd. Winario ${ }^{1)}$, Husni Fuaddi' \\ ${ }^{1)}$ Program Studi Ekonomi Islam STEI Iqra Annisa Pekanbaru \\ Surel: (mohd.winario@gmail.com)
}

\begin{abstract}
The perpetuation of this is done in Desa Indah Karya Tapung subdistrict, Kampar. This devotion aims to promote Islamic financial institutions. This activity also aims to introduce Islamic products other, so that the Muslim community familiar with Islamic financial institutions. In addition, the aim is for people wishing to set up financial institutions Baitul Mal Wat-Tamwil in the village. Extension programs can be done well and running smoothly. Its success can be seen from: 1) There are sufficient expertise in the development of BMT, because until now, financial institutions and non-bank bank very much alumni S1 and S2 in Riau. 2) The enthusiasm of the villagers the wonderful work that is high enough on the training of village development through BMT. 3) Support the head of the village hamlet beautiful works of this activity adds to the spirit of the activity of training and helping the team servants. And 4) availability of funding support from the University. Barriers views of: 1) The villagers work beautifully to both the extension still many who do not have knowledge of Islamic financial institutions. 2) Lack of implementation time extension so that some materials can not be presented in detail. and 3) The grasp of the participants varied, some are fast, but also there is slow so that the time used less than the maximum.
\end{abstract}

Key words: Counseling, BMT, Village

\begin{abstract}
ABSTRAK
Pengabadian ini dilakukan di Desa Karya Indah Kecamatan Tapung, Kabupaten Kampar. Pengabdian ini bertujuan untuk mensosialisasikan lembaga keuangan syariah. Kegiatan ini juga bertujuan untuk mengenalkan produk-produk syariah lainnya, agar masyarakat muslim familiar dengan lembaga keuangan syariah. Selain itu juga tujuannya adalah agar masyarakat berkeinginan untuk mendirikan lembaga keuangan Baitul Mal Wat-Tamwil di desa tersebut. Program penyuluhan dapat diselenggarakan dengan baik dan berjalan dengan lancar. Keberhasilannya dapat dilihat dari: 1) Tersedia tenaga ahli yang memadai dalam pengembangan BMT, karena hingga saat ini lembaga keuangan bank dan non bank sangat banyak juga alumni S1 dan S2 di riau. 2) Antusiasme masyarakat desa karya indah yang cukup tinggi terhadap pelatihan pengembangan desanya melalui BMT. 3) Dukungan kepala dusun desa karya indah terhadap kegiatan ini menambah semangat dalam kegitan pelatihan dan membantu tim pengabdi.Dan 4) Ketersediaan dana pendukung dari Universitas. Hambatannya dilihat dari: 1) Masyarakat desa Karya indah yang merupakan peserta penyuluhan masih banyak yang belum memiliki pengetahuan tentang lembaga keuangan syariah. 2) Keterbatasan waktu pelaksanaan penyuluhan sehingga beberapa materi tidak dapat disampaikan secara detil. dan 3) Daya tangkap para peserta yang bervariasi, ada yang cepat namun juga ada yang lambat sehingga waktu yang digunakan kurang maksimal.

Kata kunci: Penyuluhan, BMT, Desa
\end{abstract}


Jurnal Pengabdian Masyarakat

vol.1 no.1 Oktober 2017

\section{PENDAHULUAN}

\section{Profil}

Kabupaten Kampar memiliki dua buah sungai besar dan beberapa sungai kecil yaitu:

a. Sungai Kampar yang panjangnya $\pm 413,5 \mathrm{~km}$ dengan kedalaman rata-rata 7,7 $\mathrm{m}$ dengan lebar rata-rata 143 meter. Seluruh bagian sungai ini termasuk dalam Kabupaten Kampar yang meliputi Kecamatan XIII Koto Kampar, Bangkinang, Bangkinang Barat, Kampar, Siak Hulu dan Kampar Kiri.

b. Sungai Siak bagian hulu yakni panjangnya $\pm 90 \mathrm{~km}$ dengan kedalaman rata-rata $8-12 \mathrm{~m}$ yang melintasi kecamatan Tapung

Sungai-sungai besar yang terdapat di Kabupaten Kampar ini sebagian masih berfungsi baik sebagai prasarana perhubungan, sumber air bersih budi daya ikan maupun sebagai sumber energi listrik (PLTA Koto Panjang). Kabupaten Kampar pada umumnya beriklim tropis dengan temperatur maksimum 320C. Jumlah hari hujan dalam tahun 2006, yang terbanyak adalah disekitar Salo, Bangkinang, dan Bangkinang Seberang sedang yang paling sedikit terjadinya hujan adalah sekitar Tapung Hulu. Karya Indah merupakan salah satu desa yang ada di kecamatan Tapung, Kabupaten Kampar, provinsi Riau, Indonesia. Desa Karya Indah memiliki jumlah penduduk 5.981 orang. (Wikipedia).

\section{Kondisi}

Kabupaten Kampar memiiliki potensi kekayaan alam yang cukup melimpah salah satunya adalah memiliki sungai-sungai yang kaya dengan potensi alamnya, baik dari sungai-sungai besar maupun sungai-sungai kecil yang berada di wilayah Kabupaten Kampar tersebut. Berdasarkan data yang diperoleh dari Bappeda Kampar RTRW 2000, Dinas PU/Kimpraswil Kampar dan Provinsi melalui Badan Lingkungan Hidup Kabupaten Kampar, tahun 2009, Kabupaten Kampar memiliki 554 sungai-sungai besar dan kecil. Sungai Siak bagian hulu yang merupakan sungai kedua terbesar di kabupaten Kampar ini jika ditinjau lebih ke hulunya lagi yakni anak-anak sungainya ada salah satu anak sungai/sungai kecilnya yang menjadi tujuan favorit oleh para pemancing untuk memancing di sungai tersebut baik sebagai mata pencaharian perekonomiannya maupun sebagai memenuhi hobi yang sekaligus menjadikan objek pariwisatanya.

Dari pengamatan yang telah penulis lakukan langsung kelokasi tersebut, yang tepatnya bernama Sungai Kandis, Desa Karya Indah, Kecamatan Tapung Kabupaten Kampar, maka dapat diperoleh beberapa informasi dari masyarakat setempat bahwa pemancing yang datang kebanyakan pada hari Sabtu dan Minggu, berdasarkan kondisi alam yakni berkisaran bulan April-Agustus merupakan pengunjung yang datang untuk memancing paling padat dibandingkan pada bulan September-Maret, dikarenakan pada bulan April-Agustus volume air sungai Kandis tersebut dalam kondisi normal, sedangkan pada bulan September-Maret volume air sungai Kandis tersebut tinggi/dalam bahkan terkadang banjir. Menurut perkiraan masyarakat setempat yang memberikan jasa penyewaan perahu/sampan untuk para pemancing yang ingin menggunakan perahu/sampan, dalam kondisi volume air sungai normal pengunjung yang datang untuk memancing rerata lebih kurang 180 orang perminggu, sedangkan ketika kondisi volume air sungai naik/tinggi rerata lebih kurang 20 orang perminggunya, hal ini diperkirakannya berdasarkan banyaknya jumlah perahu/sampan yang disewa oleh para pemancing serta banyaknya kenderaan sepeda motor yang parkir di lahannya. Meskipun sungai ini sangat 
Jurnal Pengabdian Masyarakat

vol.1 no.1 Oktober 2017

berpotensi besar dan banyak dikunjungi oleh para pemancing, namun sampai sekarang belum ada campur tangan pemerintah dalam pelestarian potensi tersebut.

\section{Peta Desa Karya Indah}

Berikut ini adalah peta lokasi wilayah Desa Karya Indah Kecamatan Tapung, Kabupaten Kampar.

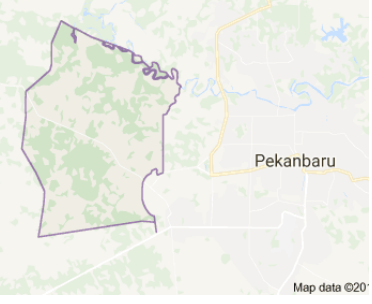

Gambar 1. Peta Desa Karya Indah Kec. Tapung, Kab. Kampar

Desa Karya Indah sebagaimana desa lainnya terletak di Kecamatan Tapung yang letak Desanya berbatasan dengan:

a. Sebelah utara berbatasan dengan Desa Bencah Kelubi

b. Sebelah selatan berbatasan dengan Desa Rimbo Panjang

c. Sebelah Barat berbatasan dengan Desa Sei. Putih Benca Indah

d. Sebelah Timur berbatasan dengan Desa Sim. Baru.(Dokumentasi, dari kantor Kepala Desa Karya Indah)

Desa Karya Indah yang luas wilayahnya lebih kurang 1.484 ha, memiliki iklim sedang karena terletak di daratan rendah. Sedangkan mesim yang terjadi di Desa Karya Indah ada dua yaitu musim hujan dan musim kemarau.

Desa Karya Indah mempunyai Tiga (3) Dusun yaitu:

a. Dusun I

b. Dusun II

c. Dusun III

Masing-masing Dusun dipimpin oleh seorang Kepala Dusun, yang pengangkatannya dilakukan dengan cara pemilihan berdasarkan suara terbanyak dalam wilayah kerja Dusun masing-masing. Dan sebagaimana biasanya setiap Desa memiliki daerah bagian RW dan RT, maka untuk lebih jelasnya dapat dilihat pada tabel berikut ini:

Tabel 1 Jumlah Dusun, RW dan RT Desa Karya Indah

\begin{tabular}{|c|l|l|c|}
\hline No & \multicolumn{1}{|c|}{ Nama Daerah } & \multicolumn{1}{|c|}{ Jumlah RW } & Jumlah RT \\
\hline 1 & Dusun & 2 RW $(01,02)$ & 5 RT \\
\hline 2 & Dusun & 2 RW $(03,04)$ & 6 RT \\
\hline 3 & Dusun & 3 RW $(05,06,07)$ & 6 RT \\
\hline & Jumlah & 6 & 17 \\
\hline
\end{tabular}

Sumber Data: Kantor Kepala Desa Karya Indah

Pembagian daerah di atas mencakup daerah seluas 150.000 ha dengan jumlah penduduk sebanyak 2.543 jiwa atau 620 KK. Data yang diperoleh dari kantor Kepala Desa Karya Indah Kecamatan Tapung tahun 2008 berjumlah 2.543 jiwa yang terdiri dari: 
Tabel 2 Jumlah Penduduk Desa Karya Indah

\begin{tabular}{|c|l|c|c|}
\hline No & \multicolumn{1}{|c|}{ Jenis Kelamin } & Jumlah & Persentase \\
\hline 1 & Laki-laki & 1.158 & $45,54 \%$ \\
\hline 2 & Perempuan & 1.385 & $54,46 \%$ \\
\hline & Jumlah & 2.543 & $100,00 \%$ \\
\hline
\end{tabular}

Sumber Data: Kantor Kepala Desa Karya Indah

Dari tabel di atas dapatlah diketahui bahwa penduduk yang terbanyakadalah jenis kelamin perempuan yaitu 1.385 jiwa, sedangkan jenis kelamin laki-laki sebanyak 1.158 jiwa.

Penduduk Desa Karya Indah terdiri dari berbagai suku bangsa seperti suku Melayu, suku Jawa, suku Batak, suku Minang, dan lain-lain. Untuk lebih jelas dapat dilihat pada tabel berikut:

Tabel 3 Jumlah Penduduk Menurut Suku Bangsa

\begin{tabular}{|c|l|c|c|}
\hline No & Jenis Suku Bangsa & Jumlah & Persentase \\
\hline 1 & Suku Melayu & 902 & $35,47 \%$ \\
\hline 2 & Suku Batak & 287 & $11,29 \%$ \\
\hline 3 & Suku Jawa & 731 & $28,75 \%$ \\
\hline 4 & Suku Minang & 560 & $22,02 \%$ \\
\hline 5 & Lain-lain & 63 & $2,47 \%$ \\
\hline & Jumlah & 2.543 & $100,00 \%$ \\
\hline
\end{tabular}

Sumber Data: Kantor Kepala Desa Karya Indah

Dari tabel di atas dapatlah diketahui bahwasanya masyarakat yang ada di Desa Karya Indah merupakan masyarakat yang multi etnis. Ini terlihat dari beragam suku bangsa yang terdapat dalam masyarakat yang ada di daerah tersebut. Kebanyakan dari jumlah penduduk Desa Karya Indah adalah suku Melayu yang terdiri dari masyarakat asli Desa Karya Indah, kemudian disusul oleh suku Jawa, Batak, Minang. Masyarakat Desa Karya Indah pada umumnya bekerja sebagaipetani (kebun karet, lahan petani) dan nelayan (perikanan). Bertani dan berkebun merupakan penghasilan pokok masyarakat, sedangkan penghasilan lain merupakan penghasilan tambahan.

Dalam kehidupan ekonomi secara umum masyarakat bekerja dibidang pertanian di samping itu ada juga yang bekerja dibidang tertentu, untuk lebih jelasnya dapat dilihat pada tabel berikut:

Tabel Jumlah Penduduk Berdasarkan Mata Pencarian

\begin{tabular}{|c|l|c|c|}
\hline No & Pekerjaan & Jumlah & Porsentase \\
\hline 1 & Petani & 681 & $56,47 \%$ \\
2 & PNS & 37 & $3,07 \%$ \\
3 & Tukang & 23 & $1,91 \%$ \\
4 & Buruh Tani & 115 & $9,54 \%$ \\
5 & Karyawan & 29 & $2,40 \%$ \\
6 & Pegawai Swasta & 126 & $10,45 \%$ \\
7 & Nelayan & 103 & $8,54 \%$ \\
8 & Dagang & 92 & $7,62 \%$ \\
\hline & Jumlah & 1.206 & $100,00 \%$ \\
\hline
\end{tabular}


Jurnal Pengabdian Masyarakat

vol.1 no.1 Oktober 2017

Sumber Data: Kantor Kepala Desa Karya Indah

Dari tabel di atas dapat dilihat bahwa mayoritas pekerjaan penduduk Desa Karya Indah adalah petani, yakni petani perkebunan kelapa sawit. Kemudian dari jumlah seluruh penduduk yaitu 2.543 jiwa dapat dilihat pada tabel, bahwa hampir seperuhnya tidak bekerja, tetapi sesungguhnya kebanyakan dari mereka sudah lanjut usia dan tidak mampu lagi untuk bekerja. sedangkan sebagian lagi masih anak-anak dan masih menuntut ilmu di daerah atau diluar daerahnya sendiri.

\section{IDENTIFIKASI DAN PERUMUSAN MASALAH}

1. Batasan Masalah

Dalam pengabdian masyarakat ini menmfokuskan pada upaya pendirian Baitul mal wat tamwil di Desa Karya Indah Kecamatan Tapung, Kabupaten Kampar.

2. Rumusan Masalah

Bagaimanakah potensi BMT dan Upaya Pendirian BMT di Desa Karya Indah Kec. Tapung Kabupaten Kampar.

\section{TINJAUAN PUSTAKA}

Sejarah berdirinya BMT dimulai dari ide para aktivis Masjid Salman ITB Bandung yang mendirikankoperasi Jasa Keahlian Teknosa pada tahun 1980. Koperasi inilah yang menjadi cikal bakal BMT yang berdiri pada tahun 1984. Seiring kebutuhan masyarakat akan lembaga keuangan mikro serta kebijakan pemerintah yang mendorong tumbuh kembangnya lembaga keuangan mikro, maka peluang pengembangan BMT sangatlah besar.

Nama Baitul Mal Wat Tamwil (BMT) jika dirunut dari kata pembentuknya, ia tersusun atas dua kata golongan yang masng-masing mempunyai makna sendiri, yakni Baitul Maaldan Baituttamwil. Baitul Maaladalah lembaga keuangan yang berorientasi sosial keagamaan yang kegiatan utamanya menampung serta menyalurkan harta masyarakat berupa zakat, infaqdan shadaqah(ZIS), sesuai dengan ketentuan yang ditetapkan dalam Al Quran dan Hadits.(Makhalul Ilmi, 2002).

Pada tatanan hukum di Indonesia, badan hukum untuk BMT adalah koperasi. Koperasi berlandaskan Pancasila dan Undang Undang Dasar Negara Republik Indonesia Tahun 1945. Koperasi berdasar atas asas kekeluargaan serta bertujuan meningkatkan kesejahteraan Anggota pada khususnya dan masyarakat pada umumnya, sekaligus sebagai bagian yang tidak terpisahkan dari tatanan perekonomian nasional yang demokratis dan berkeadilan.(Undang-Undang Republik Indonesia, Nomor 17 Tahun 2012 Tentang Perkoperasian, pasal 1, ayat 14: 3).

Ciri utamayang membedakan BMT dengan lembaga keuangan lainya antaralain(Ridwan, 2004: 132):Berorientasi bisnis, mencari laba bersama, meningkatkan pemanfaatan ekonomi paling banyak untuk anggota dan masyarakat, bermanfaat untuk mengefektifkan pengumpulan dan penyaluran dana zakat, infaq dan sedekah bagi kesejahteraan orang banyak.

Dengan demikian keberadaan BMT menjadi organisasi yang sah dan legal. Sebagai lembaga keuangan syariah, BMT harus berpegang teguh pada prinsip-prinsip syariah. Keimanan menjadi landasan atas keyakinan untuk mau tumbuh dan berkembang. Keterpaduan mengisyaratkan adanya harapan untuk mencapai sukses di dunia dan akhirat, dan juga keterpaduan antara sisi maal dan tamwil (sosial dan bisnis). Kekeluargaan dan kebersamaan berarti upaya untuk mencapai kesuksesan tersebut dapat diraih secara bersama. Kemandirian 
Jurnal Pengabdian Masyarakat

vol.1 no.1 Oktober 2017

berarti tidak dapat hidup hanya dengan bergantung pada uluran tangan pemerintah, tetapi harus berkembang dari meningkatkan partisipasi anggota dan masyarakat, untuk itulah pola pengelolaannya harus professional. (Muhammad Ridwan, 2004: 130).

Asas danlandasan BMT adalah Pancasila dan UUD 1945 serta berprinsip Syari' ah Islam, keimanan, keterpaduan (kaffah),kekeluargaan/koperasi, kebersamaan, kemandirian dan profesionalisme (Ridwan, 2004:129).

\section{TUJUAN KEGIATAN}

Tujuan dari kegiatan pengabdian masyarakat ini adalah: Untuk mengetahui potensi BMT dan mengupayakan pendirian BMT di Desa Karya Indah Kec. Tapung Kabupaten Kampar.

\section{MANFAAT KEGIATAN}

Manfaat kegiatan pengabdian masyarakat ini adalah sebagai berikut:

1. Masyarakat Desa Karya Indah mengetahui pentingnya lembaga keuangan syariah (BMT)

2. Masyarakat bersemangat untuk mendirikan lembaga keuangan syariah (BMT).

3. Mengaplikasikan ilmu ke masyarakat terutama di Desa Karya Indah Kec. Tapung Kabupaten Kampar.

\section{KHALAYAK SASARAN}

Agar pengabdian masyarakat ini mengenai sasaran, maka pengabdian ini melibatkan para pemangku kebijakan dan masyarakat Desa Karya Indah Kecamatan Tapung, Kabupaten Kampar, sehingga potensi dan peluang berdirinya BMT di Desa Karya Indah bisa terwujud.

\section{METODE PENERAPAN}

Metode yang digunakan dalam kegiatan pengabdian ini adalah dengan metode ceramah, diskusi, dan tanya jawab, serta pembimbingan dan pendampingan kepada Masyarakat Desa Karya Indah, Kecamatan Tapung, Kabupaten Kampar tentang pengetahuan dan penjelasan tentang pentingnya lembaga keuangan syariah.

\section{HASIL DAN PEMBAHASAN}

Masyarakat Desa Karya Indah adalah masyarakat yang mayoritasnya adalah muslim, hal ini dapat dilihat dari tabel berikut ini:

Tabel Jumlah Penduduk Berdasarkan Agama

\begin{tabular}{|c|l|c|c|}
\hline No & \multicolumn{1}{|c|}{ Agama } & Jumlah & Persentase \\
\hline 1 & Islam & 2.476 & $97,37 \%$ \\
\hline 2 & Kristen & 67 & $2,63 \%$ \\
\hline \multicolumn{2}{|c|}{ Jumlah } & $\mathbf{2 . 5 4 3}$ & $\mathbf{1 0 0 \%}$ \\
\hline
\end{tabular}

Dari tabel di atas dapat dilihat bahwa warga Desa Karya Indah mayoritas beragama Islam sebesar 97,37\%, dan selebihnya beragama Kristen yaitu sebesar 2,63\%.

Masyarakat Desa Karya Indah Kec. Tapung Kab. Kampar tergolong masyarakat pedesaan yang mempunyai rasa social yang tinggi. Rasa social yang berbentuk seperasaan, saling memerlukan dan rasa sepenanggungan yang terlihat pada kehidupan sehari-hari. Hal ini sesuai dengan peribahasa yang mengatakan "berat sama dipikul ringan sama dijinjing". 
Jurnal Pengabdian Masyarakat

vol.1 no.1 Oktober 2017

Soerjono Soekanto mengatakan, ciri-ciri masyarakat yang memiliki rasa sosial sebagai berikut:

a. Seperasaan, yaitu seseorang berusaha untuk mengidentifikasikan dirinya dengan sebanyak mungkin kedala suatun kelompok tertentu, sehingga dirinya merupakan bagian dari kelompok tersebut. Segala keperluannya diselaraskan dengan keperluan kelompoknya sebagai struktur social masyarakat.

b. Saling memerlukan, yaitu mempunyai ikatan antara individu dengan individu yang lain, sehingga terciptalah kerjasama yang baik antara kelompok tersebut.

c. Sepenanggungan, yaitu apapun yang terjadi dengan masyarakat tersebut, mereka merasa berada dala satu kelompok sehingga mereka merasa mempunyai kedudukan yang pasti

Dalam kehidupan ekonomi secara umum masyarakat bekerja dibidang pertanian di samping itu ada juga yang bekerja dibidang tertentu, untuk lebih jelasnya dapat dilihat pada tabel berikut:

Tabel Jumlah Penduduk Berdasarkan Mata Pencarian

\begin{tabular}{|c|l|c|c|}
\hline No & Pekerjaan & Jumlah & Porsentase \\
\hline 1 & Petani & 681 & $56,47 \%$ \\
2 & PNS & 37 & $3,07 \%$ \\
3 & Tukang & 23 & $1,91 \%$ \\
4 & Buruh Tani & 115 & $9,54 \%$ \\
5 & Karyawan & 29 & $2,40 \%$ \\
6 & Pegawai Swasta & 126 & $10,45 \%$ \\
7 & Nelayan & 103 & $8,54 \%$ \\
8 & Dagang & 92 & $7,62 \%$ \\
\hline & Jumlah & 1.206 & $100,00 \%$ \\
\hline
\end{tabular}

Sumber Data: Kantor Kepala Desa Karya Indah

Dari tabel di atas dapat dilihat bahwa mayoritas pekerjaan penduduk Desa Karya Indah adalah petani, yakni petani perkebunan kelapa sawit. Kemudian dari jumlah seluruh penduduk yaitu 2.543 jiwa dapat dilihat pada tabel, bahwa hampir seperuhnya tidak bekerja, tetapi sesungguhnya kebanyakan dari mereka sudah lanjut usia dan tidak mampu lagi untuk bekerja. sedangkan sebagian lagi masih anak-anak dan masih menuntut ilmu di daerah atau diluar daerahnya sendiri.

Pengabdian ini dilakukan dengan cara memberikan penyuluhan pentingnya lembaga keuangan mikro syariah, dikarenakan masyarakat riau umumnya adalah muslim, masyarakat Kampar juga mayoritas muslim walaupun di Desa Karya Indah ini masyarakat banyak juga yang beragama non muslim, namun mayoritas masyarakat di desa ini masih muslim, sehingga kesempatan dan peluang untuk mendirikan BMT sangat besar.

Kegiatan PPM yang dilaksanakan dengan tatap muka dan Tanya jawab. Pertemuan tatap muka dengan metode ceramah dan presentasi, dilanjutkan Tanya jawab seputar lembaga kueangan syariah.

Pelaksanan kegiatan PPM ini dilakukan oleh 2 (tiga) orang tim pengabdi dengan pokok bahasan yang disampaikan mengenai:

a. Pemahaman tentang ekonomi islam

b. Pentingnya lembaga keuangan syariah 
c. Profil lembaga keuangan syariah yang sukses

d. Daerah yang maju melalui lembaga keuangan syariah

Keterbatasan waktu pertemuan mengakibatkan tidak semua materi dapat disampaikan dengan detil dan panjang lebar.

Hasil kegiatan PPM secara garis besar mencakup beberapa komponen sebagai berikut:

a. Keberhasilan target jumlah peserta pelatihan

Target peserta penyuluhan seperti direncanakan sebelumnya adalah paling 30 peserta, Dalam pelaksanaannya, kegiatan ini diikuti oleh 20 orang peserta. Dengan demikian dapat dikatakan bahwa target peserta tercapai $75 \%$. Angka tersebut menunjukkan bahwa kegiatan pengabdian masyarakat dilihat dari jumlah peserta yang mengikuti dapat dikatakan berhasil/ sukses.

b. Ketercapaian tujuan pelatihan

Ketercapaian tujuan penyuluhan lembaga keuangan syariah secara umum sudah baik, namun keterbatasan waktu yang disediakan mengakibatkan tidak semua materi tentang lembaga keuangan syariah dan materi pengantar ekonomi islam dapat disampaikan secara detil.

c. Ketercapaian target materi yang telah direncanakan

Ketercapaian target materi pada kegiatan pengabdian masyarkat ini cukup baik, karena materi penyuluhan telah dapat disampaikan secara keseluruhan. Materi pendampingan yang telah disampaikan adalah:

1) Pengantar ekonomi islam.

2) Pentingnya lembaga keuangan syariah.

3) Profil lembaga keuangan syariah.

4) Keberhasilan daerah yang menerapkan lembaga keuangan syariah.

a. Kemampuan peserta dalam penguasaan materi

Kemampuan peserta dilihat dari penguasaan materi masih kurang dikarenakan waktu yang singkat dalam penyampaian materi dan kemampuan para peserta yang berbeda-beda. Hal ini disebabkan jumlah materi yang banyak hanya disampaikan dalam waktu sehari sehingga tidak cukup waktu bagi para peserta untuk memahami dan mempraktekkan secara lengkap semua materi yang diberikan.

Secara keseluruhan kegiatan penyuluhan ini dapat dikatakan berhasil. Keberhasilan ini selain diukur dari keempat komponen di atas, juga dapat dilihat dari kepuasan peserta setelah mengikuti kegiatan. Manfaat yang diperoleh peserta adalah pengetahuan dan pemahaman tentang lembaga keuangans syariah.

\section{KESIMPULAN}

Program penyuluhan dapat diselenggarakan dengan baik dan berjalan dengan lancar sesuai dengan rencana kegiatan yang telah disusun meskipun belum semua peserta penyuluhan menguasai dengan baik materi yang disampaikan. Kegiatan ini mendapat sambutan sangat baik terbukti dengan keaktifan peserta mengikuti penyuluhan dengan tidak meninggalkan tempat sebelum waktu pelatihan berakhir.

a. Keberhasilan

1) Tersedia tenaga ahli yang memadai dalam pengembangan BMT, karena hingga saat ini lembaga keuangan bank dan non bank sangat banyak juga alumni sarjana ekonomi syariah dan magister ekonomi syariah di riau sangat banyak. 
2) Antusiasme masyarakat desa karya indah yang cukup tinggi terhadap pelatihan pengembangan desanya melalui BMT.

3) Dukungan kepala dusun desa karya indah terhadap kegiatan ini menambah semangat dalam kegitan pelatihan dan membantu tim pengabdi mengorganisasikan waktu dan tempat pelaksanaan kegiatan.

4) Ketersediaan dana pendukung dari Universitas melaui guna penyelenggaraan kegiatan pengabdian pada masyarakat ini.

b. Hambatan

1. Masyarakat desa Karya indah yang merupakan peserta penyuluhan masih banyak yang belum memiliki pengetahuan tentang lembaga keuangan syariah (BMT)

2. Keterbatasan waktu untuk pelaksanaan penyuluhan sehingga beberapa materi tidak dapat disampaikan secara detil.

3. Daya tangkap para peserta yang bervariasi, ada yang cepat namun juga ada yang lambat sehingga waktu yang digunakan kurang maksimal, sehingga waktu yang ada tidak cukup untuk menjelaskan semuanya.

\section{UCAPAN TERIMAKASIH}

Pengabdian ini merupakan bagian dari kegiatan dosen STEI Iqra Annisa untuk mengetahui potensi lembaga keuangan syariah berbentuk BMT di desa-desa,terutama di Desa Karya Indah, Kecamatan Tapung, Kabupaten Kampar.

\section{DAFTAR PUSTAKA}

[1] Dokumentasi, dari kantor Kepala Desa Karya Indah.

[2] https://id.wikipedia.org/wiki/Daftar_desa_dan_kelurahan_di_Kabupaten_Kampar\#Keca matan_Tapung

[3] Makhalul Ilmi, Teori dan Praktek Lembaga Mikro Keuangan Syariah, UII Press, Yogyakarta, 2002

[4] Ridwan, Muhammad, Manajemen Baitul Maal wa Tamwil (BMT), Yogyakarta: UII Press, 2004.

[5] Undang-Undang Republik Indonesia, Nomor 17 Tahun 2012 Tentang Perkoperasian. 